\title{
Débat avec les responsables scientifiques de l'axe 1
}

\section{(2) OpenEdition}

1 Journals

Édition électronique

URL : http://journals.openedition.org/communicationorganisation/1984

DOI : 10.4000/communicationorganisation. 1984

ISSN : $1775-3546$

Éditeur

Presses universitaires de Bordeaux

\section{Édition imprimée}

Date de publication : 1 novembre 1997

ISSN : 1168-5549

\section{Référence électronique}

"Débat avec les responsables scientifiques de l'axe 1 ", Communication et organisation [En ligne],

12 | 1997, mis en ligne le 26 mars 2012, consulté le 01 mai 2019. URL : http://

journals.openedition.org/communicationorganisation/1984; DOI : 10.4000/

communicationorganisation. 1984

Ce document a été généré automatiquement le 1 mai 2019.

(c) Presses universitaires de Bordeaux 


\section{Débat avec les responsables scientifiques de l'axe 1}

Annie Gilles 